\title{
Infection with Hepatitis C Virus among HIV-Infected Pregnant Women in Thailand
}

\author{
Denise J. Jamieson, ${ }^{1}$ Natapakwa Skunodom, ${ }^{2}$ Thanyanan Chaowanachan, ${ }^{2}$ Anuvat Roongpisuthipong, ${ }^{3}$ \\ William A. Bower, ${ }^{4}$ Tawee Chotpitayasunondh, ${ }^{5}$ Wendy Bhanich Supapol, ${ }^{6}$ Wendi L. Kuhnert, ${ }^{4}$ \\ Wimol Siriwasin, ${ }^{7}$ Jeffrey Wiener, ${ }^{1}$ Sanay Chearskul,, ${ }^{3}$ Michelle S. McConnell, ${ }^{2}$ and Nathan Shaffer ${ }^{8}$
}

${ }^{1}$ Division of Reproductive Health, Centers for Disease Control and Prevention, Atlanta, GA 30341-3717, USA

${ }^{2}$ Thailand MOPH-U.S. CDC Collaboration, CDC, Nonthaburi 11000, Thailand

${ }^{3}$ Faculty of Medicine Siriraj Hospital, Mahidol Univeristy, Siriraj, Bangkoknoi, Bangkok 10700, Thailand

${ }^{4}$ Division of Viral Hepatitis, Centers for Disease Control and Prevention, Atlanta, GA 30333, USA

${ }^{5}$ Queen Sirikit National Institute of Child Health, Department of Medical Services, Ministry of Public Health, Bangkok 10400, Thailand

${ }^{6}$ Department of Public Health Sciences, Faculty of Medicine, University of Toronto, Toronto, Canada ON M5S $1 A 8$

${ }^{7}$ Department of Medical Services, Rajavithi Hospital, Ministry of Public Health (MOPH), Bangkok 10400, Thailand

${ }^{8}$ Global AIDS Program, Centers for Disease Control and Prevention, Atlanta, GA 30333, USA

Correspondence should be addressed to Denise J. Jamieson, djj0@cdc.gov

Received 5 March 2008; Revised 28 June 2008; Accepted 3 November 2008

Recommended by Daniel Landers

\begin{abstract}
Objective. The purpose of this study was to describe the epidemiology of coinfection with hepatitis C virus (HCV) and HIV among a cohort of pregnant Thai women. Methods. Samples from 1771 pregnant women enrolled in three vertical transmission of HIV studies in Bangkok, Thailand, were tested for HCV. Results. Among HIV-infected pregnant women, HCV seroprevelance was $3.8 \%$ and the active HCV infection rate was 3.0\%. Among HIV-uninfected pregnant women, $0.3 \%$ were HCV-infected. Intravenous drug use by the woman was the factor most strongly associated with HCV seropositivity. Among 48 infants tested for HCV who were born to HIV/HCV coinfected women, two infants were HCV infected for an HCV transmission rate of 4.2\% (95\% 0.51-14.25\%). Conclusions. HCV seroprevalence and perinatal transmission rates were low among this Thai cohort of HIV-infected pregnant women.
\end{abstract}

Copyright (c) 2008 Denise J. Jamieson et al. This is an open access article distributed under the Creative Commons Attribution License, which permits unrestricted use, distribution, and reproduction in any medium, provided the original work is properly cited.

\section{INTRODUCTION}

Worldwide, the hepatitis $\mathrm{C}$ virus (HCV) seroprevalence rate among pregnant women is approximately $1 \%[1]$. This is similar to the $1.6 \%$ prevalence of $\mathrm{HCV}$ antibody in the general population in the United States [2]. Among HIVinfected pregnant women, much higher prevalences of $\mathrm{HCV}$ positivity have been reported, ranging from as high as 30 to $50 \%$ in some settings $[3,4]$, particularly in populations with high rates of injection drug use.

Although the perinatal transmission rate of $\mathrm{HCV}$ is estimated to be less than 5\% among HIV-uninfected women, it is generally higher in HIV-infected women [1]. Not all studies, however, have found increased HCV transmission rates among HIV-infected women [5] and a wide range of estimates of the risk of vertical transmission of HCV among coinfected women has been reported with wide geographic variation $[6,7]$.

The purpose of this study was to describe the epidemiology of coinfection with hepatitis $\mathrm{C}$ virus and HIV among a cohort of pregnant Thai women.

\section{MATERIALS AND METHODS}

The current study population includes 1771 women previously enrolled in three vertical transmission studies in Bangkok, Thailand [8-10] who had specimens available for HCV testing. From the first study (peri-1), 342 HIV-uninfected women and 293 HIV-infected women are included. From the second (peri-2) and third studies (peri-3), 391 and 745 HIV-infected women are included, respectively. Women in these studies were either enrolled 
during antenatal care (peri-1 and 2) or at delivery (peri3). All children born to HIV-infected women were followed for 4-18 months and their mothers did not breastfeed. No follow-up information is available for infants born to HIVuninfected women in peri-1. Peri-1 was an observational prospective cohort study without treatment interventions, peri-2 was a randomized placebo-controlled clinical trial assessing the efficacy of short-course zidovudine prophylaxis antenatally and intrapartum, and peri-3 was an observational study of short-course zidovudine and single-dose nevirapine propylaxis. All three studies were conducted jointly by the Thailand Ministry of Public Health and the U.S. Centers for Disease Control and Prevention (CDC) at two large Bangkok hospitals from 1992 to 2004. The three perinatal studies (peri-1,2,3) and this current retrospective laboratory study were all approved by the institutional review boards at the CDC in Atlanta and the Ethical Review Committees for Research in Human Subjects at the Thailand Ministry of Public Health and Siriraj Hospital in Bangkok.

In the original studies, specimens were collected and tested for HIV, HIV viral load, CD4 count as previously described $[8,9]$. Stored plasma specimens from pregnancy or delivery were screened for antibodies to HCV (antiHCV) using enzyme immunoassay (EIA; Abbott Murex version 4.0, Abbott Laboratories, Abbott Park, Ill USA). All positive EIAs were tested with qualitative reverse transcriptase polymerase chain reaction (RT-PCR; Ampliscreen, Roche Diagnostic Systems, Branchburg, NJ, USA). If the qualitative RT-PCR was negative, the plasma specimen was retested with recombinant immunoblot assay (RIBA 3.0, Chiron Corporation, Emeryville, Calif, USA). All women who were EIA positive and either qualitative RT-PCR or RIBA positive are considered HCV infected (either current or past); all other women are considered HCV uninfected. All specimens with detectable virus were tested with quantitative PCR (COBAS Amplicor HCV Monitor Test, version 2.0, Roche Diagnostic Systems) with a lower limit of detection of $<600$ copies $/ \mathrm{mL}$. All women with detectable virus are considered to have active HCV infection. Specimens with detectable HCV were genotyped using the Trugene HCV $5^{\prime} \mathrm{NC}$ genotyping kit (Bayer HealthCare LLC, Berkeley, Calif, USA) and sequence analysis with the OpenGene DNA sequencing system. Results were then confirmed using sequence analysis (ABI PRISM 310 Genetic Analyzer, Applied Biosystems, Calif, USA) methods. In 8 cases where the results from the two techniques were discordant, the 715 nt E1-E2 region at position 883-1597 nt was directly sequenced.

Stored plasma from infants born to women coinfected with HIV and HCV was also tested for HCV. An HCVinfected infant was defined as an infant who was anti-HCV positive (i.e., EIA-positive with confirmatory RIBA) at 18 months of age or older or who had positive HCV RNA on two occasions. Several serial samples from infants were tested, depending on availability of samples and testing results, since $\mathrm{HCV}$ infection often cannot be excluded in infants by onetime testing [11]. However, due to limited availability infant specimens, $18 / 48(37.5 \%)$ of infants tested had testing at only one time point.
Statistical analyses were performed using SAS software version 9.1 (SAS Institute, Cary, NC, USA). Odds ratios with 95\% confidence intervals were estimated using unconditional logistic regression, adjusting for the three perinatal studies. Ninety-five percent confidence intervals for $\mathrm{HCV}$ transmission rates were estimated using exact binomial methods.

\section{RESULTS}

There were low rates of intravenous drug use (1.5\%) among the 1771 women included in this study (Table 1). A higher proportion of women reported several other risk factors for hepatitis $\mathrm{C}$ acquisition, including having an injection drugusing partner $(10.2 \%)$ and ever having been a commercial sex worker $(7.8 \%)$. HIV-infected women had moderately high CD 4 counts at delivery (mean 428 cells $/ \mathrm{mm}^{3}$ ); the mean viral load at delivery was 10000 copies $/ \mathrm{mL}$.

Among 1429 HIV-infected pregnant women 62 (4.3\%) were found to have HCV antibodies by EIA. Of those, 54 had positive confirmatory testing by either RT-PCR $(n=43)$ or by RIBA $(n=11)$. Thus, 3.8\% (54/1429) of HIV-infected pregnant women were found to be coinfected with $\mathrm{HCV}$ and 3.0\% (43/1429) had evidence of active infection. Among 342 HIV-uninfected women, $2(0.6 \%)$ were found to have $\mathrm{HCV}$ antibodies by EIA. Of those, only one of the women had positive confirmatory testing by RT-PCR. Thus, $0.3 \%$ (1/342) of HIV-uninfected pregnant women were found to be infected with $\mathrm{HCV}$.

Among the $54 \mathrm{HCV}$-seropositive women, $22 \mathrm{did}$ not receive any antiretroviral prophylaxis, 22 received 4 weeks of antenatal zidovudine and intrapartum zidovudine, and 10 received 4 weeks of antenatal zidovudine and intrapartum zidovudine and nevirapine. Of the $43 \mathrm{HIV}$-infected women with quantifiable HCV, the serum levels of HCV RNA were as follows: 12 women with $<100000$ copies $/ \mathrm{mL}, 17$ women with $100000-850000$ copies $/ \mathrm{mL}$, and 13 women with >850 000 copies/mL. One woman who was HCV RNAPCR positive on the qualitative assay had undetectable virus ( $<600$ copies/mL) on the quantitative assay. The HIVuninfected woman with quantifiable HCV had a serum level of HCV of 62000 copies/mL. The HIV-infected women in later cohorts (peri-2 and peri-3) were more likely to be HCV infected (4.1 and 4.4\%, resp.) compared with HIV-infected women in the earlier cohort (1.7\%) (see Table 1). Among the $35 \mathrm{HCV}$-infected women with confirmed HCV genotyping results, 14 (40\%) were genotype 3a, 14 (40\%) were genotype 1a, $4(11.4 \%)$ were genotype $1 b, 2(5.7 \%)$ were genotype $6 a$, and $1(2.9 \%)$ was genotype 4 a.

In unadjusted analyses, factors associated with pregnant women being $\mathrm{HCV}$ infected included more education, intravenous drug use, having a partner with a history of injection drug use, ever having been a commercial sex worker, and having received a blood transfusion. These risk factors remained significant when adjusting for perinatal study (Table 2). In a multivariate model adjusted for all covariates in Table 2, only three factors remained significant: intravenous drug use (adjusted odds ratio 70.5; 95\% CI 24.8-201), having a partner with a history of injection drug 
TABle 1: Demographic and clinical characteristics of 1771 women enrolled in 3 vertical transmission HIV studies in Bangkok, Thailand, 1992-2004 (n (\%)).

\begin{tabular}{|c|c|c|c|c|c|}
\hline & $\begin{array}{c}\text { Peri-1 } \\
(H I V-) \\
(n=342) \\
\end{array}$ & $\begin{array}{c}\text { Peri-1 } \\
(H I V+) \\
(n=293) \\
\end{array}$ & $\begin{array}{c}\text { Peri-2 } \\
(n=391)\end{array}$ & $\begin{array}{c}\text { Peri-3 } \\
(n=745)\end{array}$ & $\begin{array}{c}\text { Total } \\
(n=1771)\end{array}$ \\
\hline \multicolumn{6}{|l|}{ HCV status } \\
\hline Infected & $1(0.3)$ & $5(1.7)$ & $16(4.1)$ & $33(4.4)$ & $55(3.1)$ \\
\hline Uninfected & $341(99.7)$ & $288(98.3)$ & $375(95.9)$ & $712(95.6)$ & $1716(96.9)$ \\
\hline \multicolumn{6}{|l|}{ Education } \\
\hline Primary or less & $227(66.4)$ & $197(67.2)$ & $225(57.5)$ & $418(56.1)$ & $1067(60.3)$ \\
\hline Greater than primary & $115(33.6)$ & $96(32.8)$ & $166(42.5)$ & $327(43.9)$ & $704(39.8)$ \\
\hline \multicolumn{6}{|l|}{ Marital status } \\
\hline Married & $179(52.3)$ & $174(59.4)$ & $185(47.3)$ & $248(33.3)$ & $786(44.4)$ \\
\hline Not married & $163(47.7)$ & $119(40.6)$ & $206(52.7)$ & $497(66.7)$ & $985(55.6)$ \\
\hline \multicolumn{6}{|l|}{$\begin{array}{l}\text { Intravenous drug user } \\
\text { (IDU) }\end{array}$} \\
\hline Yes & 0 & $3(1.0)$ & $5(1.3)$ & $19(2.6)$ & $27(1.5)$ \\
\hline No & $342(100)$ & $290(99.0)$ & $386(98.7)$ & $726(97.5)$ & $1744(98.5)$ \\
\hline \multicolumn{6}{|l|}{ Any partners IDU* } \\
\hline Yes & $5(1.5)$ & $20(7.1)$ & $38(10.6)$ & $102(15.9)$ & $165(10.2)$ \\
\hline No & $335(98.5)$ & $260(92.9)$ & $321(89.4)$ & $539(84.1)$ & $1455(89.8)$ \\
\hline \multicolumn{6}{|l|}{$\begin{array}{l}\text { Ever a commercial sex } \\
\text { worker* }\end{array}$} \\
\hline Yes & $6(1.8)$ & $30(10.2)$ & $36(9.3)$ & $66(8.9)$ & $138(7.8)$ \\
\hline No & $336(98.3)$ & $263(89.8)$ & $353(90.8)$ & $679(91.1)$ & $1631(92.2)$ \\
\hline \multicolumn{6}{|l|}{$\begin{array}{l}\text { Received transfusion } \\
(1985-89)^{*+}\end{array}$} \\
\hline Yes & $5(1.5)$ & $3(1.0)$ & $10(2.6)$ & $15(2.0)$ & $33(1.9)$ \\
\hline No & $334(98.5)$ & $290(99.0)$ & $380(97.4)$ & $730(98.0)$ & $1734(98.1)$ \\
\hline \multicolumn{6}{|l|}{ HIV subtype* } \\
\hline $\mathrm{E}$ & - & $273(95.5)$ & $318(88.8)$ & $559(88.7)$ & $1150(90.3)$ \\
\hline B & - & $10(3.5)$ & $22(6.2)$ & $45(7.1)$ & $77(6.0)$ \\
\hline $\mathrm{E} / \mathrm{B}$ & - & $3(1.1)$ & $16(4.5)$ & $12(1.9)$ & $31(2.4)$ \\
\hline $\mathrm{BR} / \mathrm{MN} / \mathrm{C}$ & - & 0 & $2(0.6)$ & $14(2.2)$ & $16(1.3)$ \\
\hline \multicolumn{6}{|l|}{ Delivery type* } \\
\hline Cesarean & - & $33(11.3)$ & $56(14.3)$ & $188(25.2)$ & $277(19.4)$ \\
\hline Vaginal & - & $260(88.7)$ & $335(85.7)$ & $557(74.8)$ & $1152(80.6)$ \\
\hline $\begin{array}{l}\text { Maternal age, years } \\
{[\text { mean (range) }]}\end{array}$ & $\begin{array}{c}24.5 \\
(15-40)\end{array}$ & $23.2(14-40)$ & $24.9(17-39)$ & $26.3(15-48)$ & $\begin{array}{c}25.1 \\
(14-48)\end{array}$ \\
\hline $\begin{array}{l}\text { Age at 1st intercourse } \\
{[\text { mean (range) }]}\end{array}$ & $\begin{array}{c}20.0 \\
(13-32)\end{array}$ & $19.3(11-35)$ & $19.4(12-32)$ & $18.6(7-44)$ & $19.2(7-44)$ \\
\hline Gravidity [mean (range)] & $1.8(1-4)$ & $1.6(1-4)$ & $1.8(1-11)$ & $2.1(1-7)$ & $1.9(1-11)$ \\
\hline $\begin{array}{l}\text { Number of sex partners in } \\
\text { past year [mean (range)] }\end{array}$ & $1.0(1-2)$ & $1.8(1-200)$ & $1.1(1-6)$ & $6.9(1-1428)$ & $\begin{array}{c}3.6 \\
(1-1428)\end{array}$ \\
\hline $\begin{array}{l}\text { Number of hours in labor } \\
\text { [mean (range)] }\end{array}$ & - & $7.4(0-28)$ & $10.6(0-57.9)$ & $14.4(0-386)$ & $\begin{array}{c}12.0 \\
(0-386)\end{array}$ \\
\hline $\begin{array}{l}\text { Duration of membrane } \\
\text { rupture, hours [mean } \\
\text { (range)] }\end{array}$ & - & $3.4(0-96)$ & $4.0(0-39.5)$ & $3.0(0-148)$ & $3.4(0-148)$ \\
\hline $\begin{array}{l}\text { HIV viral load at delivery, } \\
\log _{10} \text { copies } / \mathrm{mL}[\text { mean } \\
(\text { range })]\end{array}$ & - & $4.4(2.3-6.2)$ & $4.2(2.3-5.9)$ & $3.8(2.3-6.0)$ & $\begin{array}{c}4.0 \\
(2.3-6.2)\end{array}$ \\
\hline
\end{tabular}


TABLE 1: Continued.

\begin{tabular}{lcccc}
\hline & $\begin{array}{c}\text { Peri-1 } \\
(\text { HIV }-) \\
(n=342)\end{array}$ & $\begin{array}{c}\text { Peri-1 } \\
(\text { HIV }+)\end{array}$ & $\begin{array}{c}\text { Peri-2 } \\
(n=293)\end{array}$ & $\begin{array}{c}\text { Peri-3 } \\
(n=745)\end{array}$ \\
\hline $\begin{array}{l}\text { CD4 count at delivery, } \\
\text { cells } / \mathrm{mm}^{3} \text { [mean (range)] }\end{array}$ & - & $\begin{array}{c}(n-1) \\
(n=1771)\end{array}$ & 428 \\
\hline
\end{tabular}

* Sample size is decreased due to missing data.

+ Thailand began screening blood for HIV in 1989.

TABLE 2: Odds of being HCV-infected among 1771 pregnant women enrolled in 3 vertical transmission HIV studies in Bangkok, Thailand, 1992-2004.

\begin{tabular}{|c|c|c|c|c|c|}
\hline & \multicolumn{3}{|c|}{$H C V$-infection } & \multirow[b]{2}{*}{ OR $(95 \% \mathrm{CI})$} & \multirow{2}{*}{$\begin{array}{c}\text { Adjusted }^{*} \\
\text { OR }(95 \% \text { CI })\end{array}$} \\
\hline & No. & $\%$ & $(n)$ & & \\
\hline \multicolumn{6}{|l|}{ Education } \\
\hline Primary or less & 1067 & 2.3 & $(24)$ & 1.0 & 1.0 \\
\hline Greater than primary & 704 & 4.4 & $(31)$ & $2.00(1.16-3.44)$ & $1.81(1.05-3.12)$ \\
\hline \multicolumn{6}{|l|}{ Marital status } \\
\hline Married & 786 & 2.3 & (18) & $0.60(0.34-1.06)$ & $0.72(0.40-1.29)$ \\
\hline Not married & 985 & 3.8 & $(37)$ & 1.0 & 1.0 \\
\hline \multicolumn{6}{|l|}{ Intravenous drug user (IDU) } \\
\hline Yes & 27 & 74.1 & $(20)$ & $140(55.4-351)$ & $126(48.6-326)$ \\
\hline No & 1744 & 2.0 & $(35)$ & 1.0 & 1.0 \\
\hline \multicolumn{6}{|l|}{ Any partners IDU ${ }^{+}$} \\
\hline Yes & 165 & 14.6 & $(24)$ & $9.74(5.42-17.5)$ & $7.92(4.34-14.4)$ \\
\hline No & 1455 & 1.7 & $(25)$ & 1.0 & 1.0 \\
\hline \multicolumn{6}{|l|}{ Ever a commercial sex worker ${ }^{+}$} \\
\hline Yes & 138 & 6.5 & $(9)$ & $2.40(1.15-5.02)$ & $2.17(1.03-4.54)$ \\
\hline No & 1631 & 2.8 & $(46)$ & 1.0 & 1.0 \\
\hline \multicolumn{6}{|l|}{ Received transfusion $(1985-89)^{+}$} \\
\hline Yes & 33 & 12.1 & $(4)$ & $4.65(1.57-13.7)$ & $4.22(1.41-12.6)$ \\
\hline No & 1734 & 2.9 & $(50)$ & 1.0 & 1.0 \\
\hline Maternal age, years & - & - & - & $0.98(0.93-1.04)$ & $0.96(0.90-1.02)$ \\
\hline Gravidity & - & - & - & $1.17(0.93-1.47)$ & $1.09(0.86-1.38)$ \\
\hline Number of sex partners in past year & - & - & - & $1.00(0.996-1.005)$ & $1.00(0.996-1.005)$ \\
\hline
\end{tabular}

*Adjusted for three perinatal studies.

${ }^{+}$Sample size is decreased due to missing data.

use (adjusted odds ratio 3.4; 95\% CI 1.5-7.4), and having received a blood transfusion (adjusted odds ratio 6.7; 95\% CI 1.9-23.9). Since HIV-uninfected women were only included in peri-1, we included only women in peri-1 when estimating the odds of HCV infection by HIV status. This study did not find an association between HIV infection status and HCV infection (adjusted odds ratio 5.9; 95\% CI 0.7-51.0).

For peri-1, all 5 infants born to $\mathrm{HIV} / \mathrm{HCV}$-infected women had samples tested for HCV RNA at 2, 4, and 6 months and no infants were found to be HCV infected. For peri-2, 12/16 infants had 6-month samples available which were tested for HCV RNA and 13/16 infants had 18-month samples available which were tested for HCV antibodies. All infants had testing from at least one time point and 10 infants were tested at more than one time point. From peri2, one infant was HCV-RNA positive at 6 months; additional testing of a 4-month sample from this infant confirmed that this infant was HCV-RNA positive. In addition, three infants were anti-HCV positive by EIA at 18 months. However, only one of these infants had positive confirmatory testing by RIBA. For peri-3, 15 infants had serial testing at both 2 and 4 months and 27 infants had testing performed for at least one time point. No infants were found to be HCV infected.

In summary, among 48 infants tested for $\mathrm{HCV}$ who were born to $\mathrm{HIV} / \mathrm{HCV}$ coinfected women, two infants were $\mathrm{HCV}$ infected for an HCV transmission rate of $4.2 \%$ (95\% 0.51-14.25\%). One of these infants was born to a woman who was infected with HCV genotype $3 \mathrm{a}$ and had an HCV viral load of 764323 copies/mL and an HIV viral load of 2092 copies/mL. The mother of this infant received zidovudine for 4 weeks antenatally and during labor; this infant was HIV uninfected. The other infant was born to a woman who was infected with HCV genotype 1a and had an HCV viral load of $>850000$ copies/mL and an HIV viral load of 20 342. The mother of this infant did not receive any antiretroviral prophylaxis; this infant was HIV infected. 
TABLE 3: HIV/HCV status and clinical characteristics of infants born to 1429 HIV-infected women enrolled in 3 vertical transmission of HIV studies in Bangkok, Thailand, 1992-2004 ( $n(\%))$.

\begin{tabular}{|c|c|c|c|c|}
\hline & $\begin{array}{c}\text { Peri-1 } \\
(n=293)\end{array}$ & $\begin{array}{c}\text { Peri-2 } \\
(n=391)\end{array}$ & $\begin{array}{c}\text { Peri-3 } \\
(n=745)\end{array}$ & Total \\
\hline \multicolumn{5}{|l|}{ HIV status of infant* } \\
\hline Infected & $68(24.4)$ & $55(14.4)$ & $52(7.5)$ & $175(12.9)$ \\
\hline Uninfected & $211(75.6)$ & $327(85.6)$ & $646(92.6)$ & $1184(87.1)$ \\
\hline \multicolumn{5}{|l|}{ HCV status of infant } \\
\hline Infected & 0 & $2(0.5)$ & 0 & $2(0.1)$ \\
\hline Uninfected & $293(100)$ & $389(99.5)$ & $745(100)$ & $1427(99.9)$ \\
\hline \multicolumn{5}{|l|}{ Infant gender } \\
\hline Male & $136(46.4)$ & $207(52.9)$ & $365(49.0)$ & $708(49.6)$ \\
\hline Female & $157(53.6)$ & $184(47.1)$ & $380(51.0)$ & $721(50.5)$ \\
\hline \multicolumn{5}{|l|}{ Birthweight } \\
\hline$<2500 \mathrm{~g}$ & $31(10.6)$ & $31(7.9)$ & $81(10.9)$ & $143(10.0)$ \\
\hline$\geq 2500 \mathrm{~g}$ & $262(89.4)$ & $360(92.1)$ & $664(89.1)$ & $1286(90.0)$ \\
\hline $\begin{array}{l}\text { Gestational age [mean } \\
\text { (range)] }\end{array}$ & $39.4(28-44)$ & $39.7(35-45)$ & $38.7(31-44)$ & $\begin{array}{c}39.1 \\
(28-45)\end{array}$ \\
\hline
\end{tabular}

* Sample size is decreased due to missing data.

The HIV vertical transmission rate among infants born to the $1429 \mathrm{HIV}$-infected women was $12.9 \%$ (Table 3 ). There was a $9.4 \%(5 / 53) \mathrm{HIV}$ transmission rate among $\mathrm{HCV}$ infected mothers and a 13.0\% (170/1306) HIV transmission rate among $\mathrm{HCV}$-uninfected mothers $(P=.445)$. The odds of an infant being HIV infected did not differ significantly by the mother's HCV status neither in unadjusted analyses (odds ratio $0.70 ; 95 \%$ CI $0.27-1.77$ ), nor in analyses adjusted for perinatal study (adjusted odds ratio 0.82; 95\% CI $0.32-2.12)$.

\section{CONCLUSIONS}

$\mathrm{HCV}$ infection in pregnancy is emerging as an increasingly important issue. Due to improved HCV blood screening, mother-to-child transmission of $\mathrm{HCV}$ has now replaced transfusion-associated transmission as the predominant mode of spread in children [1]. In this retrospective analysis of more than 1700 pregnant women in Thailand, most of whom were HIV infected, we found relatively low hepatitis $\mathrm{C}$ seroprevalence rates. Among the HIV-infected pregnant women, HCV seroprevalence was 3.8\% and active $\mathrm{HCV}$ infection was 3.0\%. Among HIV-uninfected pregnant women, HCV seroprevalence was $0.3 \%$. The low rate of injection drug use in the population (1.5\%) likely accounts for this relatively low HCV seroprevalence, which is only slightly higher than many general populations of pregnant women who are HIV uninfected. (1) In a study conducted in Thailand from 1993-1994 among a convenience sample of $120 \mathrm{HIV}$-infected women, $6.7 \%$ were anti-HCV positive by EIA [12]. In another study in Thailand in 1991, 2.7\% of 883 women admitted to the hospital with gynecologic abnormalities had HCV antibodies [13]. Among Thai women reporting injection drug use, higher HCV prevalence rates have been reported, with $15 \%$ of 200 female injection drug users HCV infected in a recent study [14].
The risk factors for $\mathrm{HCV}$ infection identified, which included more education, intravenous drug use, having a partner with a history of injection drug use, ever having been a commercial sex worker, and having received a blood transfusion, were similar to risk factors associated with $\mathrm{HCV}$ in prior studies [15]. Although the number of HIVuninfected women was small in this study, we did not find HIV infection to be a significant risk factor for HCV infection. As expected, a history of injection drug use was the strongest predictor of HCV infection (adjusted OR 126; 95\% CI 48.6-326), similar to other studies among blood donors which have also identified injection drug use as a strong risk factor for HCV infection [15]. There are six major HCV genotypes, which are numbered 1-6 and subtyped a, b, and c. Type $1 \mathrm{~b}$ is the most common genotype worldwide. Types $1 \mathrm{a}$ and $3 \mathrm{a}$, which were the predominant genotypes in the present study, are largely associated with injection drug use $[16,17]$.

In the United States, routine HCV screening is recommended for persons with certain high-risk characteristics (e.g., history of injection drug use or blood transfusion) and for children born to HCV-infected women [18]. However, routine screening is not recommended for pregnant women without other risk factors [19]. U.S. guidelines also recommend that HIV-infected persons be routinely screened for HCV [20]. In Thailand, although current national guidelines do not address routine HCV screening or hepatitis testing for HIV-infected patients, most physicians provide hepatitis testing for HIV-infected adults with symptoms or risk factors, and pediatric providers in tertiary care centers often test HIV-infected children who are at risk. Pregnant women in antenatal clinics are also routinely screened for hepatitis B, but not HCV. HCV treatment is available in Thailand at cost to patients or to patients with private health insurance.

The HCV perinatal transmission rate among infants born to $\mathrm{HIV} / \mathrm{HCV}$ coinfected women in this study was $4.2 \%$. However, due to the small number of HCV-infected 
women in our sample, the confidence interval was wide. The estimated frequency of $\mathrm{HCV}$ transmission in this current study is similar to those of two recent multicenter studies conducted among mostly HIV-uninfected women in the United States [21] and Europe [22] which reported transmission rates of $3.6 \%$ and $6.2 \%$, respectively. Since HIV-infected women in this cohort had relatively high CD4 counts at delivery, it is not clear how generalizable these findings are to other cohorts of HIV-infected pregnant women. Although the published literature has shown a correlation of maternal HCV viral load and the risk of HCV vertical transmission [4, 23], there were too few HCV mother-to-child transmission in our study to draw conclusions. However, both HCVinfected infants born to HIV-infected women had high HCV viral loads.

\section{ACKNOWLEDGMENTS}

The authors wish to thank the TUC laboratory staff for their outstanding work processing and testing all the specimens, and Daniel Newman for his extensive assistance with data management for the study. This study received funding from the Opportunistic Infections Working Group at the Centers for Disease Control and Prevention. The findings and conclusions in this article are those of the authors and do not necessarily represent the official position of the Centers for Disease Control and Prevention.

\section{REFERENCES}

[1] E. A. Roberts and L. Yeung, "Maternal-infant transmission of hepatitis C virus infection," Hepatology, vol. 36, no. 5B, pp. S106-S113, 2002.

[2] G. L. Armstrong, A. Wasley, E. P. Simard, G. M. McQuillan, W. L. Kuhnert, and M. J. Alter, "The prevalence of hepatitis C virus infection in the United States, 1999 through 2002," Annals of Internal Medicine, vol. 144, no. 10, pp. 705-714, 2006.

[3] V. Papaevangclou, H. Pollack, G. Rochford, et al., "Increased transmission of vertical hepatitis $\mathrm{C}$ virus (HCV) infection to human immunodeficiency virus (HIV)-infected infants of HIV- and HCV-coinfected women," The Journal of Infectious Diseases, vol. 178, no. 4, pp. 1047-1052, 1998.

[4] D. L. Thomas, S. A. Villano, K. A. Riester, et al., "Perinatal transmission of hepatitis $\mathrm{C}$ virus from human immunodeficiency virus type 1-infected mothers," The Journal of Infectious Diseases, vol. 177, no. 6, pp. 1480-1488, 1998.

[5] D. Conte, M. Fraquelli, D. Prati, A. Colucci, and E. Minola, "Prevalence and clinical course of chronic hepatitis $\mathrm{C}$ virus (HCV) infection and rate of HCV vertical transmission in a cohort of 15,250 pregnant women," Hepatology, vol. 31, no. 3, pp. 751-755, 2000.

[6] S. L. Thomas, M.-L. Newell, C. S. Peckham, A. E. Ades, and A. J. Hall, "A review of hepatitis C virus (HCV) vertical transmission: risks of transmission to infants born to mothers with and without $\mathrm{HCV}$ viraemia or human immunodeficiency virus infection," International Journal of Epidemiology, vol. 27, no. 1, pp. 108-117, 1998.

[7] L. T. F. Yeung, S. M. King, and E. A. Roberts, "Mother-toinfant transmission of hepatitis C virus," Hepatology, vol. 34, no. 2, pp. 223-229, 2001.
[8] N. Shaffer, R. Chuachoowong, P. A. Mock, et al., "Short-course zidovudine for perinatal HIV-1 transmission in Bangkok, Thailand: a randomised controlled trial," The Lancet, vol. 353, no. 9155, pp. 773-780, 1999.

[9] N. Shaffer, A. Roongpisuthipong, W. Siriwasin, et al., "Maternal virus load and perinatal human immunodeficiency virus type 1 subtype E transmission, Thailand," The Journal of Infectious Diseases, vol. 179, no. 3, pp. 590-599, 1999.

[10] A. Teeraratkul, R. J. Simonds, S. Asavapiriyanont, et al., "Evaluating programs to prevent mother-to-child HIV transmission in two large Bangkok hospitals, 1999-2001," Journal of Acquired Immune Deficiency Syndromes, vol. 38, no. 2, pp. 208-212, 2005.

[11] D. L. Thomas, "Mother-infant hepatitis C transmission: second generation research," Hepatology, vol. 29, no. 3, pp. 992-993, 1999.

[12] S. Suwanagool, S. Tieangrim, W. Ratanasuwan, S. Mekanantagosol, P. Luengrojanakul, and P. Kunasol, "Seroprevalence of anti-HCV among HIV-infected persons and general population," Journal of the Medical Association of Thailand, vol. 78, no. 11, pp. 611-617, 1995.

[13] A. Roongpisuthipong, I. Suphanit, K. Yamaguchi, et al., "The study of HCV antibody and serologic tests for syphilis in Thai patients with gynecologic disorders," Asian Pacific Journal of Allergy and Immunology, vol. 11, no. 2, pp. 135-139, 1993.

[14] J. Jittiwutikarn, S. Thongsawat, V. Suriyanon, et al., "Hepatitis $\mathrm{C}$ infection among drug users in northern Thailand," American Journal of Tropical Medicine and Hygiene, vol. 74, no. 6, pp. 1111-1116, 2006.

[15] E. L. Murphy, S. M. Bryzman, S. A. Glynn, et al., "Risk factors for hepatitis C virus infection in united states blood donors," Hepatology, vol. 31, no. 3, pp. 756-762, 2000.

[16] P. Simmonds, "Viral heterogeneity of the hepatitis C virus," Journal of Hepatology, Supplement, vol. 31, no. 1, pp. 54-60, 1999.

[17] P. Simmonds, "Genetic diversity and evolution of hepatitis C virus-15 years on," Journal of General Virology, vol. 85, no. 11, pp. 3173-3188, 2004.

[18] Centers for Disease Control and Prevention, "Recommendations for prevention and control of hepatitis $\mathrm{C}$ virus (HCV) infection and HCV-related chronic disease," MMWR Recommendations and Reports, vol. 47, no. RR-19, pp. 1-39, 1998.

[19] American College of Obstetricians and Gynecologists, "ACOG educational bulletin. Viral hepatitis in pregnancy. Number 248, July 1998 (replaces No. 174, November 1992). American College of Obstetricians and Gynecologists," International Journal of Gynecology \& Obstetrics, vol. 63, no. 2, pp. 195-202, 1998.

[20] J. E. Kaplan, H. Masur, and K. K. Holmes, "Guidelines for preventing opportunistic infections among HIV-infected persons-2002. Recommendations of the U.S. Public Health Service and the Infectious Diseases Society of America," MMWR Recommendations and Reports, vol. 51, no. RR-8, pp. 1-46, 2002.

[21] E. E. Mast, L.-Y. Hwang, D. S. Y. Seto, et al., "Risk factors for perinatal transmission of hepatitis $\mathrm{C}$ virus ( $\mathrm{HCV}$ ) and the natural history of HCV infection acquired in infancy," The Journal of Infectious Diseases, vol. 192, no. 11, pp. 1880-1889, 2005.

[22] P.-A. Tovo, L. Pembrey, and M.-L. Newell, "A significant sexbut not elective cesarean section-effect on mother-to-child transmission of hepatitis C virus infection," The Journal of Infectious Diseases, vol. 192, no. 11, pp. 1872-1879, 2005. 
[23] H. Ohto, S. Terazawa, N. Sasaki, et al., "Transmission of hepatitis C virus from mothers to infants," The New England Journal of Medicine, vol. 330, no. 11, pp. 744-750, 1994. 


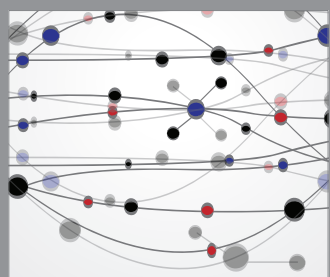

The Scientific World Journal
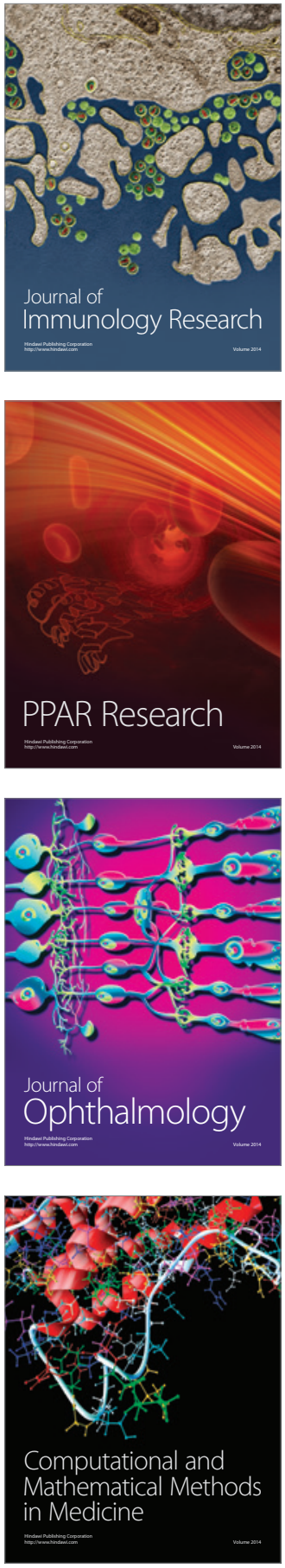

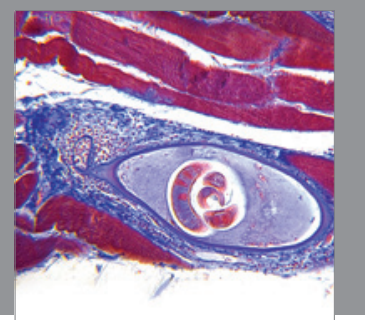

Gastroenterology

Research and Practice
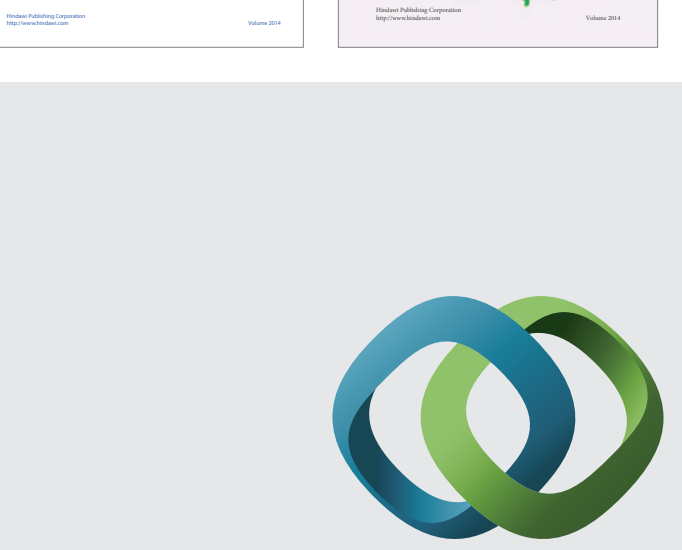

\section{Hindawi}

Submit your manuscripts at

http://www.hindawi.com
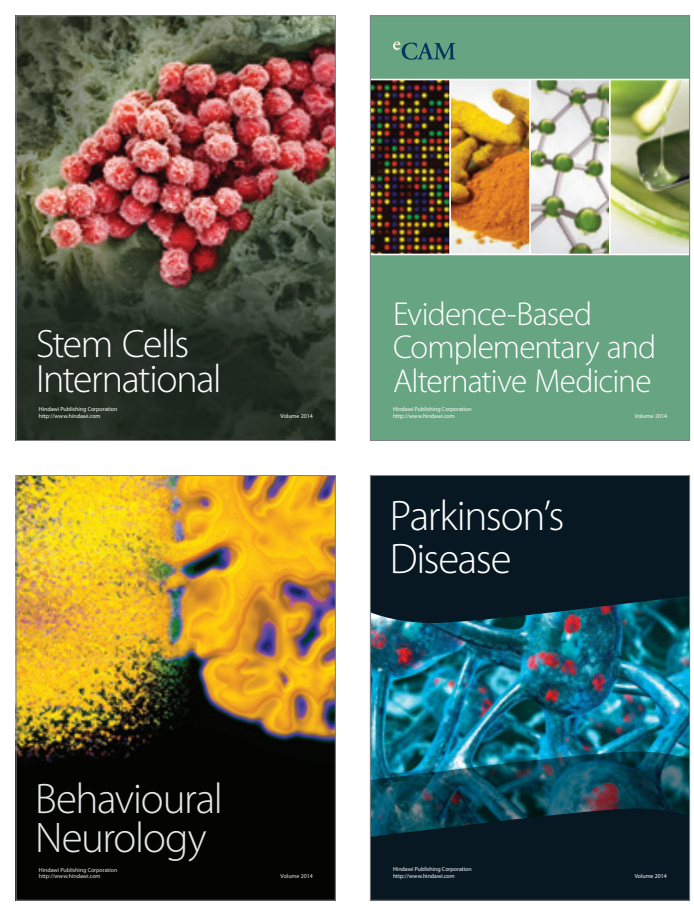

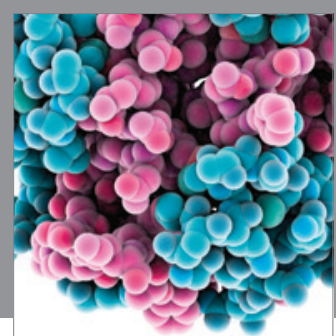

Journal of
Diabetes Research

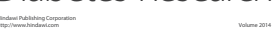

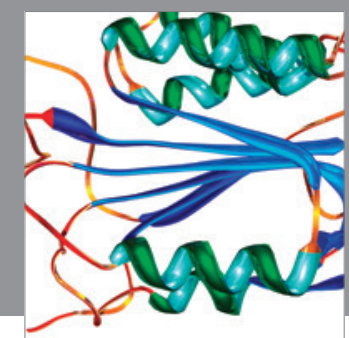

Disease Markers
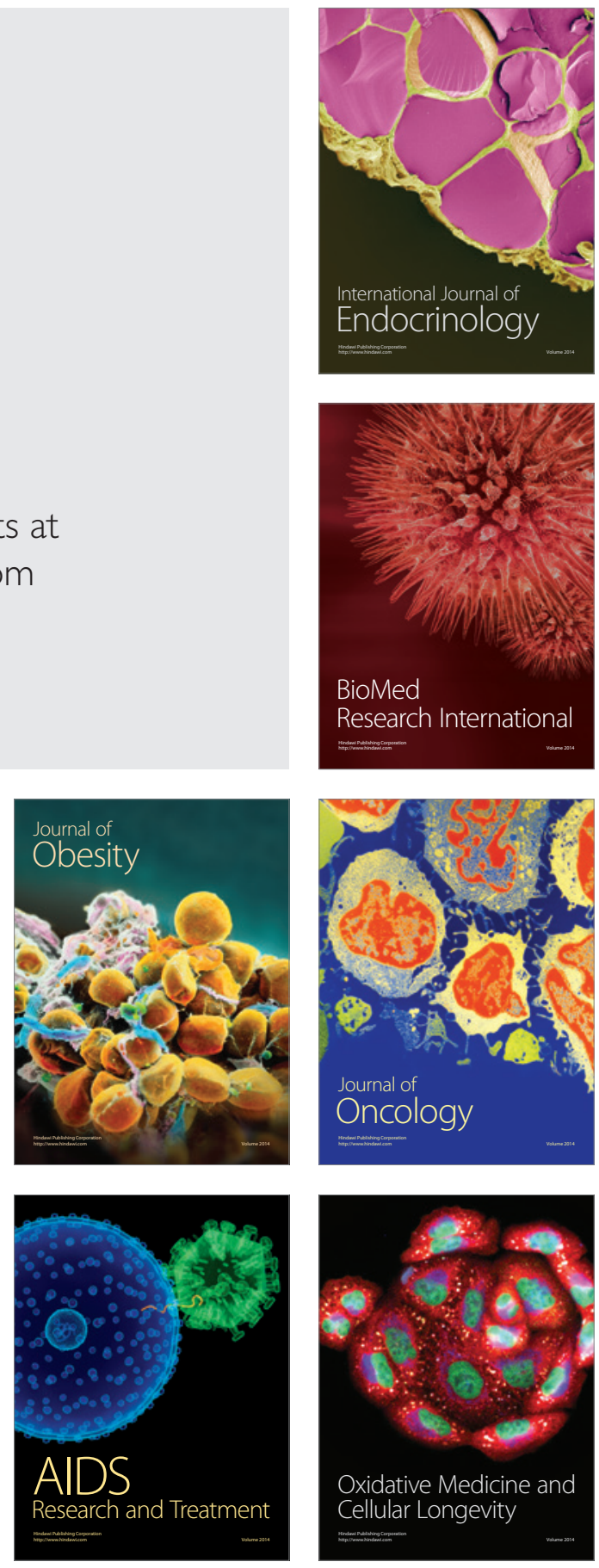